\title{
Sokoto Red and Sahelian goats: The untapped potential for improving meat production in the developing economy of Nigeria
}

${ }^{1 *}$ Adedibu, I. I., Sola- Ojo F. E. ${ }^{2}$ and Lawal, M.

A study was conducted on indigenous unselected Sokoto Red (SR) and Sahel (SH) goats in National Animal Production Research Institute, (NAPRI), Ahmadu Bello University, ShikaZaria, Kaduna State, Nigeria. The study was carried out to understand how birth, preweaning and post-weaning weights in the SR and SH goats can be used to improve their productivity. Thirty kids (10 males and 20 females) of SR and thirty kids (10 males and 20 females) of SH breeds of goat were utilised for this study. Results obtained showed that the coefficient of variation $(C V)$ was very low. There were no significant differences $(P>0.05)$ among mean bodyweight at birth, 30 days pre-weaning, 60 days pre-weaning, 90 days postweaning and 120 days post-weaning weights of SR and SH goats except at 150 days postweaning weight. Highly positive phenotypic correlations existed in the SR goats between 90 day weaning weight and 120-day post weaning; 90-day weaning weight and 150-day post weaning. 120-day post weaning weight and 150-day post weaning. The birth weight of the $S H$ goats were highly significant $(P<0.05)$ and positively correlated with body weight at 30,60, 90, 120 and 150 days old. It was observed that the sampled population was homogeneous for all traits. The 90-day weight of the SR can be utilised to improve for body weight at 30-, 120and 150-days of age while in the SH goat, selection for high birth weight would enhance improvement for high bodyweights at later stages of growth.

Keywords: Sokoto Red and Sahelian goats, comparison, coefficient of variation, bodyweight, improvement

\section{Introduction}

The indigenous unselected goats in Nigeria are characterised by poor growth performance such that they may have small body size and weight at weaning (Santra et al., 2002). The poor growth ability and bodyweight of goats have not discouraged their rearing by virtually all households in the rural communities yet they are considered veritable tools for the alleviation of poverty in Nigeria.

Based on geographical distribution, the Sokoto Red and the Sahelian goats are vastly spread across the Northern ecozones of Nigeria (Otuma and Osakwe, 2008) due to their prolificacy and adaptability to varied harsh conditions. Proper information on the pre-weaning and postweaning traits which could cause quantitative variations in these two breeds of indigenous goats in the Northern Guinea Savannah of Nigeria need to be assessed. This could be informative in future selection and improvement endeavour in goat breeding programmes (Berhane and Eik, 2006). Genetic improvement of these indigenous breeds can improve the productivity and sustainability of the goat enterprise in the tropics more rapidly than trying to improve the exotic breeds (Otuma and Osakwe, 2008). Genetic improvement for pre weaning and post weaning traits would have direct bearing on the profitability of goat production systems (Mbuku et al., 2014). The aim of this study is to understand the dynamics of birth, preweaning and post-weaning weights in the 


\section{Sokoto Red and Sahelian goats}

Sokoto Red and Sahelian goats of Nigeria in order to improve productivity in these indigenous breeds.

This study is therefore designed to evaluate and compare the Sokoto Red and Sahel goats using their pre-weaning and post weaning weights as well as estimate the relationships that exist between the preweaning and post weaning weights.

\section{Materials and methods \\ Experimental Location}

The experiment was carried out at National Animal Production Research Institute, (NAPRI), Ahmadu Bello University, Shika-Zaria, Kaduna State, Nigeria. Zaria is located between 11.11 latitude and 7.72 longitude and on an altitude of 644 meters above sea level (). The area falls within the Northern-Guinea Savannah zone of Nigeria, characterized by rainfall ranging from $1100 \mathrm{~mm}$ to $1250 \mathrm{~mm}$ annually. The area lies within the warm humid climate of the Northwest zone of the country, with clear distinctive dry and wet seasons.

\section{Experimental animals and management}

Thirty kids (10 males and 20 females) of Sokoto Red and 30 kids (10 males and 20 females) of Sahelian breeds of goat were utilised for this study. The kids were reared under the intensive system of management. The experimental kids were ear tagged and were allowed ad-libitun milk from their various dams with fresh milk supplementation until they were 30 days old. After the $30^{\text {th }}$ day, concentrate supplement containing $40 \%$ crude protein (CP) and $11.70 \mathrm{MJ}$ energy at the rate of $60 \mathrm{~g} / \mathrm{head} /$ day in addition to dam's milk were offered. Legumes were later fed postweaning when the concentrate supplementation was stopped until the kids reached 150 days.

Traits assessed

The traits evaluated in the course of the experiment, were bodyweights at birth, 30-, 60-, 90-, 120- and 150- days of age which were taken with the help of Weighbridge ${ }^{\circledR}$ (manufactured by Salter in England with a $200 \mathrm{~kg} \pm 1 \mathrm{~kg}$ calibration).

The collected data was analysed using the GLM procedure of SAS (2001) using the following model:

$$
Y_{i j}=\mu+B_{i}+e_{i j}
$$

Where $Y_{i j}=$ weight of the $\mathrm{i}^{\text {th }}$ individual

$$
\begin{aligned}
& \mu=\text { Overall mean } \\
& B_{i}=\text { effect of } i^{\text {th }} \text { breed }(1,2) \\
& e_{i j}=\text { random error }
\end{aligned}
$$

Phenotypic correlation between two variables was estimated using the PROC CORR procedure of SAS (2001).

\section{Results and discussion}

The mean body weights at birth 30,60 , 90,120 and 150 days of age for both Sokoto Red and Sahel goats (Table 1) were within the range in previous reports (Akpa 2000; Zahraddeen et al., 2008). The values obtained for the coefficient of variation (CV) indicated that the population from which these two breeds were sampled was homogenous and thus may not be suitable for selection and improvement for the traits highlighted on the Table 1 . The low values for the CV may also be attributed to the low sample size which is a major characteristic of institutional herds in the developing economy such that it hampers livestock improvement programmes (FAO, 2017).

In this study, the Sahelian goat had higher weight from birth up to weaning than the Sokoto Red goats. The Sokoto Red goats had higher bodyweight than Sahel goats thereafter at 150-day of age. Zahraddeen et al. (2008) reported that Sahelian goat was superior than Sokoto Red for birth weight to weaning. Similarly, Nkungu et al. (1995) who reported superiority of 75 and 50 percent Norwegian crosses as compared to 100 percent and 87.5 percent Norwegian goats. 
Adedibu, Sola- Ojo and Lawal

Table 1: Descriptive statistics for pre weaning and post weaning weights of Sokoto Red and Sahelian Breeds of Goat

\begin{tabular}{llll}
\hline & Trait (kg) & Mean \pm S.D & CV \\
\hline Sokoto Red & Birth weight & $1.43 \pm 0.40$ & 0.16 \\
& 30-day pre-weaning weight & $6.00 \pm 0.98$ & 0.97 \\
60-day pre-weaning weight & $9.33 \pm 0.92$ & 0.85 \\
90-day weaning weight & $13.34 \pm 1.65$ & 2.72 \\
120-days Post weaning weight & $18.63 \pm 1.88$ & 3.55 \\
Sahelian goat & 150-day Post weaning weight & $24.34 \pm 1.83$ & 3.34 \\
& Birth weight & & \\
& 30-day pre-weaning weight & $1.56 \pm 0.39$ & 0.15 \\
& 60-day pre-weaning weight & $6.27 \pm 0.83$ & 0.69 \\
& 90-day weaning weight & $13.60 \pm 1.07$ & 1.15 \\
& 120-days Post weaning weight & $18.47 \pm 1.31$ & 1.58 \\
150-day Post weaning weight & $23.47 \pm 1.20$ & 1.71 \\
\hline S.D: Standard Deviation & CV: Coefficient of Variation & & 1.43 \\
\hline
\end{tabular}

Influence of breed on pre weaning and post weaning weights of goats

There were no significant differences $(\mathrm{P}>0.05)$ between mean bodyweight at birth, 30 days pre-weaning, 60 days preweaning, 90 days post-weaning and 120 days post-weaning of Sokoto Red and Sahel goats (Table 2). Zahraddeen et al. (2008) had also reported a non significant ( $>>0.05)$ effect of breeds on birth weight of kids of Sokoto Red and Sahel goats. 150 days post-weaning weight was however significantly lower $(\mathrm{P}<0.05)$ in Sahelian goats than that of Sokoto Red goats (Table 2). Zahraddeen et al. (2008) and Alade et al. (2008) had earlier also reported a lower value for Sokoto Red than the Sahelian goats for post-weaning weights. In this study, breed had a significant influence on the 150day post weaning body weight indicating clear genetic differences (Babar et al. 2003).

Table 2: Influence of breed on pre weaning and post weaning weights of goats

\begin{tabular}{llll}
\hline & \multicolumn{2}{c}{ Breed } & SEM \\
\cline { 2 - 4 } Traits & Sokoto Red (30) & Sahelian (30) & \\
\hline Birth weight & $1.43 \pm 0.40$ & $1.56 \pm 0.39$ & 0.10 \\
30-day pre-weaning weight & $6.00 \pm 0.98$ & $6.27 \pm 0.83$ & 0.23 \\
60-day pre-weaning weight & $9.33 \pm 0.92$ & $9.60 \pm 1.07$ & 0.26 \\
90-day weaning weight & $13.37 \pm 1.65$ & $13.93 \pm 1.26$ & 0.38 \\
120-days Post weaning weight & $18.67 \pm 1.88$ & $18.47 \pm 1.31$ & 0.42 \\
150-day Post weaning weight & $24.37^{\mathrm{a}} \pm 183$ & $23.47^{\mathrm{b}} \pm 1.20$ & 0.40 \\
\hline
\end{tabular}

Interrelationships between bodyweights of Sokoto Red goats and Sahel goats

The highly positive phenotypic correlations in the Sokoto Red goats were between 90-day weaning weight and 120day post weaning; 90-day weaning weight and 150-day post weaning. 120-day post weaning weight and 150-day post weaning (Table 3). The 30-day pre-weaning weight and 90-day weaning weights had moderately positive relationships. This indicated that the body weight at 90 days of age (weaning) 


\section{Sokoto Red and Sahelian goats}

have a strong relationship with bodyweight at 30-day, 120-day and 150-day of age. This suggested that selection for any of these traits that are positively correlated would have a considerable positive impact on improving the other traits as they may be influenced by same sets of genes (pleiotropy). The implication is that as these traits are under the additive maternal effects (Rodolfo, 1984), the breeder could utilise weaning weight at 90 days of age in the Sokoto Red for improvement of the population for post weaning weights. The negative correlation observed in Sokoto Red goats between birth weight and 90 days weaning showed that selection for bodyweight at birth cannot be utilised for improvement for higher weaning weights (Burfening and Kress 1993).

The birth weight of the Sahelian goats were highly significant $(\mathrm{P}<0.05)$ and strongly positively correlated with all bodyweight at 30 days pre-weaning, 60 days pre-weaning, 90 days weaning weight, 120 days post weaning and 150 days of age (Table 3 ). This is an indication that selecting for a heavy Sahelian goat at birth would increase the chance of a bigger goat at different stages of growth that is at 30,60,120 and 150 days of age (Malau-Aduli et al., 2003; Shonibare, 2004). Future selection for bodyweight at 30 , 60,120 and 150 days of age could be fasttracked by selecting for higher birth weight (Malau-Aduli et al., 2003). The pre-weaning bodyweights (30-day and 60-day bodyweights) had highly significantly $(\mathrm{P}<0.01)$ strong positive relationships with post-weaning weights (120-day and 150day) in the Sahelian goats. Pre-weaning bodyweights are a function of birth weight and nursing which indicated maternal effect during this growth phase (Rodolfo, 1984). The relationship between the pre-weaning and post-weaning body weight indicated that, high maternal influence in the Sahelian goats still influenced post weaning bodyweights (El-Abid et al., 2008).

Table 3: Phenotypic Correlation for different bodyweights of Sokoto Red and Sahelian breeds of goats

\begin{tabular}{|c|c|c|c|c|c|c|c|}
\hline & Trait & $\begin{array}{l}\text { Birth } \\
\text { weight }\end{array}$ & $\begin{array}{l}\text { 30-day } \\
\text { pre- } \\
\text { weaning } \\
\text { weight }\end{array}$ & $\begin{array}{l}\text { 60-day } \\
\text { pre- } \\
\text { weaning } \\
\text { weight }\end{array}$ & $\begin{array}{l}\text { 90-day } \\
\text { weaning } \\
\text { weight }\end{array}$ & $\begin{array}{l}\text { 120-days } \\
\text { Post } \\
\text { weaning } \\
\text { weight }\end{array}$ & $\begin{array}{l}\text { 150-day } \\
\text { Post } \\
\text { weaning } \\
\text { weight }\end{array}$ \\
\hline \multicolumn{8}{|l|}{ Sokoto Red } \\
\hline & Birth weight & 1 & 0.17 & 0.09 & -0.08 & -0.02 & 0.15 \\
\hline & 30-day pre-weaning weight & 0.17 & 1 & 0.34 & $0.40 *$ & 0.26 & 0.33 \\
\hline & 60-day pre-weaning weight & 0.87 & 0.34 & 1 & 0.30 & 0.33 & 0.29 \\
\hline & 90-day weaning weight & -0.08 & $0.40^{*}$ & 0.30 & 1 & $0.69 * *$ & $0.64 * *$ \\
\hline & $\begin{array}{l}\text { 120-days Post weaning } \\
\text { weight }\end{array}$ & -0.02 & 0.26 & 0.33 & $0.69^{* *}$ & 1 & $0.87 * *$ \\
\hline & $\begin{array}{l}\text { 150-day Post weaning } \\
\text { weight }\end{array}$ & 0.15 & 0.35 & 0.29 & $0.64 * *$ & $0.87 * *$ & 1 \\
\hline \multicolumn{8}{|l|}{ Sahelian goat } \\
\hline & Birth weight & 1 & $0.68 * *$ & $0.77 * *$ & $0.68 * *$ & $0.79 * *$ & $0.76^{* *}$ \\
\hline & 30-day pre-weaning weight & $0.68 * *$ & 1 & $0.67 * *$ & $0.42 *$ & $0.68 * *$ & $0.61 * *$ \\
\hline & 60-day pre-weaning weight & $0.77 * *$ & $0.67 * *$ & 1 & $0.49 * *$ & $0.68 * *$ & $0.61 * *$ \\
\hline & 90-day weaning weight & $0.68 * *$ & $0.42 *$ & $0.49 * *$ & 1 & $0.71 * *$ & $0.55 * *$ \\
\hline & $\begin{array}{l}\text { 120-days Post weaning } \\
\text { weight }\end{array}$ & $0.79 * *$ & $0.58 * *$ & $0.68 * *$ & $0.71 * *$ & 1 & $0.83^{* *}$ \\
\hline & $\begin{array}{l}\text { 150-day Post weaning } \\
\text { weight }\end{array}$ & $0.76^{* *}$ & $0.58 * *$ & $0.61 * *$ & $0.55^{* *}$ & $0.83^{* *}$ & 1 \\
\hline
\end{tabular}




\section{Adedibu, Sola- Ojo and Lawal}

Multivariate analysis of the bodyweights of Sokoto Red and Sahelian goats

In the first principal component, high positive correlations were obtained (Figure 1) for birth weight, 90-day and 120-day bodyweights. Bodyweight at 90-day and birth weight are more closely related which indicated that the two traits are controlled by genes which are more likely to be located closely on the same chromosomes (genetic linkage). This indicates that they may not assort independently during meosis (www.biologyreference.com/LaMa/Linkage-and-Gene-Mapping.html) and selection for high birthweight would invariably lead to high bodyweight at 30 days of age in the Sokoto Red goats. The second principal component (Figure 1) also showed that the preweaning weights (30and 60- day weights) were correlated and the same sets of genes could be in control of these three traits.

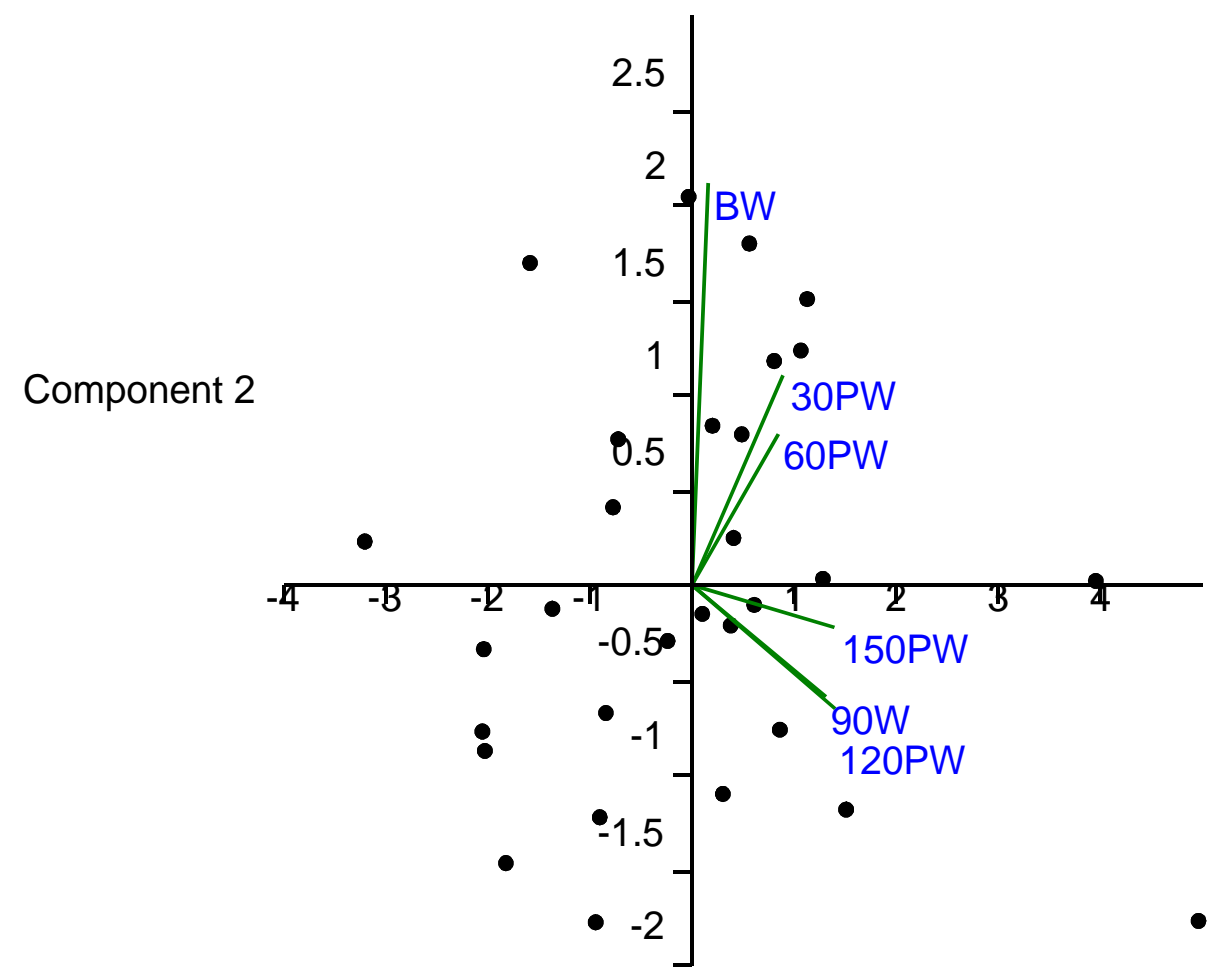

Component 1

Figure 1: Principal Components of pre weaning, weaning and post weaning weight of Sokoto Red Goats

$\mathrm{BW}=$ Birth Weight; 30PW $=30$-day pre-weaning; $60 \mathrm{PW}=60$-day pre-weaning; $90 \mathrm{PW}=90$-day weaning; $120 \mathrm{PW}=120$-day post-weaning; $150 \mathrm{PW}=150$-day post-weaning 


\section{Sokoto Red and Sahelian goats}

weaning weight (90-day bodyweight), 120-day and 150-day bodyweights were closely associated indicating that weaning weight (90-day) has a vital influence on the prospective bodyweights at 120-day and 150-day in the Sahelian goat (Zahraddeen et al., 2007). Weaning weights have been reported (Babar et al., 2003; Zahraddeen et al., 2007) to be influenced by environmental influence (mothering ability). This could be the reason why weaning weight is associated with 120-day and 150-day in the Sahelian goats in this study (Babar et al., 2003; Zahraddeen et al., 2007). In the Sahelian goats, the two traits, birth and weaning weights are the traits to select for in breeding and improvement programmes because they would serve as early markers on the genetic potential later in the life of animal (Fasae et al., 2016).

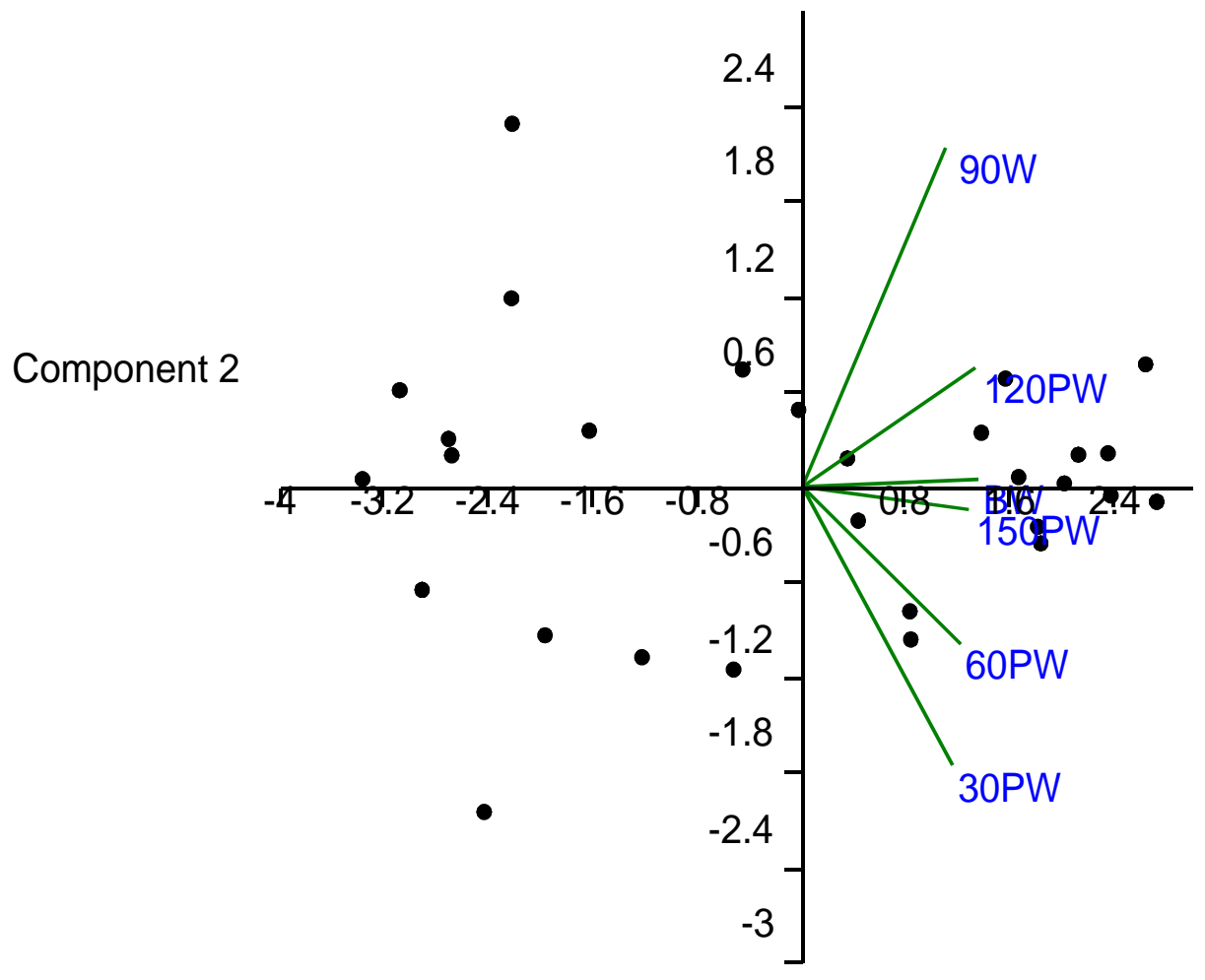

\section{Component 1}

Figure 2: Principal Components of pre weaning, weaning and post weaning weight of Sahelian goats $\mathrm{BW}=$ Birth Weight; 30PW $=30$-day pre-weaning; $60 \mathrm{PW}=60$-day pre-weaning; $90 \mathrm{PW}=90$-day weaning; $120 \mathrm{PW}=120$-day post-weaning; $150 \mathrm{PW}=150$-day post-weaning 


\section{Conclusions}

The sampled population was homogenous for all traits because of the sample size. The pre-weaning and post-weaning bodyweights of the Sokoto Red and Sahel goats were similar except for bodyweight at 150 days of age whereby the Sokoto Red was higher than the Sahel goats. The 90day bodyweight of the Sokoto Red can be utilised to improve for bodyweight at 30-, 120- and 150- days of age. In the Sahelian goat however, selection for high birth weight would enhance improvement for high body weight at later stages of growth.

\section{References}

Akpa, G. N. 2000. Factors affecting growth and body measurements of traditionally managed Sokoto Red goats. Proceedings of 27 Annual conference of Nigerian Society for Animal Production. Pp 262-263

Alade, N. K., Raji, A. O. and Atiku, M. A. 2008. Determination of appropriate model for the estimation of body weight in goats. Journal of Agricultural and Biological Science 3(4) 51-57 http://www.arpnjournals.com/jabs /research_papeSR/rp 0708 92.pd f

Babar, M. E., Ahmad, Z., Nadeem, A. and Yaqoob, M. O. 2003. Environmental factors affecting weaning weight in Lohi sheep. Pakistan Veterinary Journal 23(4) 177-180

Berhane, G. and Eik, L. O. 2006. Effect of Vetch (Vicia sativa) hay supplementation to Bergait and Abergelle goats in Northern Ethiopia. Small Ruminant Research 63:418-431

Burfening, P. J. and Kress, D. D. 1993. Direct and maternal effects on birth and weaning weight in sheep. Small Ruminant Research 10:153163

El-Abid El- Hassan, K., Babikerb, S. A. and Abu Nikihail, A. M. A. 2008. Growth rate of Sudanese Nubian kids under smallholder system. International Journal of Dairy Science 3:170-178

F A O 2017. www.fao.org/docrep/004/X6536E/ X6536E04.htm

Fasae, O. A., Oyebade, A. O., Adewumi, O. O. and James, I. J. 2016. Factors affecting birth and weaning weights in lambs in Yankasa, West African dwarf breeds and their crosses. Journal of Agricultural Science and Environment 12(2): 8995 Accessed on 28/09/2017

Makun, H. J., Umunna, N. N., Osuji, P., Agyemang, K., Alawa, J. P. and Nshalai, I. 2001. Response of growing sheep to maize stover supplemented with forage legumes (Lablab and cowpea), blood meal and mixtures of forage legumes and blood meal. Journal of Animal Production Research 17:29-47

Malau-Aduli, B. S., Eduvie, L. O., Lakpini, C. A. M. and MalauAduli, A. E. 2003. Variations in live weight gains, milk yield and composition of Sokoto Red goats fed crop residue based supplements in the sub humid zone of Nigeria. Livestock Production Science 83:63-71

Mbuku, S., ., Okeyo, M. and . 2014. Economic values for production and functional traits of Small East African goat using profit functions. Tropical Animal Health Production 46(5):789-95. doi: 10.1007/s11250014-0567-8. 


\section{Sokoto Red and Sahelian goats}

Nkungu, D. R., Kifaro, G. C. and Mtenga, L. A. 1995. Performance of dairy goats in Mgeta, Morogoro, Tanzania. S met Newsletter 28: 3-8

Otuma, M. O. and Osakwe, I. I. 2008. Estimation of genetic parameters of growth traits in Nigerian Sahelian goats. Journal of Animal and Veterinary Advances 7(5): 535-538

Rodolfo, J. C. C. 1984. Estimation of maternal effects on birth and weaning weight of Hereford cattle. A thesis submitted in partial fulfillment of the requirements for the degree of Master of Science in Animal Science Montana State University Pp 104

Santra, A., Karim, S. A. and Chaturvedi, O. H. 2002. Effect of concentrate supplementation on nutrient intake and performance of lambs of two genotypes grazing a semi arid rangeland. Small Ruminant Research 44:37-47

SAS 2001. Statistical Analysis Systems, Inc. User's Guide. Statistic version for windows, SAS Software, version 8.2 Cary, North Carolina, USA
Shonibare, O. F. 2004. Phenotypic relationship among litter size, birth weight and weaning weight in West African dwarf and Sokoto Red goats. Thesis abstract. Submitted to Department of Animal Breeding and Genetics, Federal University of Agriculture, Abeokuta. journal.unaab.edu.ng/index. $\mathrm{php/theses/thesis/view/230.}$ Downloaded at $4.05 \mathrm{pm}$ on 22/08/2017

Zahradeen, D., Butswat, I. S. R and Mbap, S. T. 2007. Goat production and management in Bauchi State, Nigeria. Proceedings of the $21^{\mathrm{si}}$ Annual conference of Farm management association of Nigeria (FAMAN) held at Olabisi Onabanjo University, Ogun State, Nigeria 231-240

Zahradeen, D., Butswat, I. S. R. and Mbap, S. T. 2008. Evaluation of some factors influencing growth performance of local goats in Nigeria. African Journal of Food Agriculture Nutrition and Development 8(4) 464-479

Received: $10^{\text {th }}$ July, 2017 Accepted: $9^{\text {th }}$ December, 2017 